\title{
PEMANFAATAN LINGKUNGAN SEBAGAI MEDIA PEMBELAJARAN GEOGRAFI MATERI LINGKUNGAN HIDUP DAN PEMBANGUNAN BERKELANJUTAN DALAM MENINGKATKAN HASIL BELAJAR GEOGRAFI KELAS XI IPS 1 SMAN 1 LAWA
}

\author{
Wa Ode Nur Kardila ${ }^{1}$ \\ ${ }^{1}$ Alumni Pendidikan Geografi Universitas Halu Oleo
}

\begin{abstract}
Abstrak : Tujuan penelitian ini adalah (1) untuk mengetahui aktivitas guru dalam pemanfaatan lingkungan sebagai media pembelajaran Geografi (2) untuk mengetahui aktivitas siswa dalam pemanfaatan lingkungan sebagai media pembelajaran (3) Untuk mengetahui peningkatan hasil belajar siswa dalam pemanfaatan lingkungan sebagai media pembelajaran Geografi. Penelitian ini berbentuk Penelitian Tindakan Kelas (PTK) yang meliputi empat tahapan yaitu: perencanaan, pelaksanaan, observasi dan refleksi yang dilakukan dalam dua siklus. Subjek penelitian ini adalah siswa kelas XI IPS 1 SMAN 1 Lawa yang berjumlah 25 siswa. Teknik dan instrumen penelitian ini adalah (1) lembar observasi aktivitas guru (2) lembar observasi aktivitas siswa (3) tes hasil belajar. Analisis data pada penelitian ini menggunakan deskriptif persentase. Berdasarkan hasil analisis data penelitian didapatkan bahwa (1) aktivitas guru, aktivitas siswa dan hasil belajar siswa yang ditandai dengan aktivitas guru dalam mengelola pembelajaran pada siklus I adalah $77,8 \%$ dan pada siklus II adalah $86,9 \%$, (2) Sedangkan aktivitas siswa selama kegiatan pembelajaran siklus I menunjukkan persentase $70,5 \%$ dan siklus II sebanyak 83,3\%. (3) Hasil belajar pada siklus I berjumlah $56 \%$ dan pada siklus II sebanyak $84 \%$, dan tes akhir sebanyak $88 \%$ Dengan demikian, pemanfaatan lingkungan sebagai media pembelajaran dapat meningkatkan hasil belajar siswa kelas XI IPS 1 SMAN 1 Lawa.
\end{abstract}

Kata Kunci : Pemanfaatan Lingkungan, Media, Hasil Belajar 
Jurnal Penelitian Pendidikan Geografi Volume 4. No 2 April 2019

\title{
THE USE OF THE ENVIRONMENT AS A MEDIUM FOR GEOGRAPHYLEARNING OF ENVIRONMENTAL AND SUSTAINABLE DEVELOPMENTSUBJECT IN IMPROVING THE LEARNING OUTCOMES OF GEOGRAPHY CLASS IN XI IPS 1 SMAN 1 LAWA
}

\author{
Wa Ode Nur Kardila ${ }^{1}$ \\ ${ }^{1}$ Alumni of Halu Oleo University Geography Education
}

\begin{abstract}
This study aims to (1) to know the activity of teachers in the utilization of the environment as a medium of learning Geography (2) to know the activity of students in the utilization of the environment as a medium of learning Geography (3) improvement of student learning outcomes in the utilization of environment as media To mengetehui science lesson. This research is in the form of Class Action Research (PTK) which includes four stages: planning, execution, observation and reflection done in two cycles. The subjects of this study are the students of grade XI IPS 1 SMANegeri 1 LAWA, amounting to 25 students. The techniques and instruments of this study are tests and observations. Data analysis in this research use descriptive percentage. The result of the research shows that there is an increase of teacher activity, student activity and student learning result which is marked by teacher ability in managing learning in cycle I is $77,8 \%$ and in cycle II is $85,1 \%$. While student activity during learning activity cycle I showed percentage of $78,3 \%$ and cycle II as much as $80,4 \%$. Student learning outcomes through environmental media in the initial test as much as $56 \%$, continue to increase in the first cycle amounted to $56 \%$ and in the second cycle as much as $84 \%$, while the final test amounted to $88 \%$. Thus, the utilization of the environment as a medium of learning can improve student learning outcomes grade XI IPS 1 SMANegeri 1 LAWA.
\end{abstract}

\section{Keywords: Environmental Utilization, Media, Learning Outcomes}

\section{PENDAHULUAN}

Pendidikan merupakan salah satu sarana untuk meningkatkan kecerdasan dan keterampilan manusia sehingga kualitas sumber daya manusia sangat tergantung dari kualitas pendidikan. Melalui pendidikan dapat mengembangkan kemampuan pribadi, daya pikir dan tingkah laku yang lebih baik. Sekolah sebagai pelaksana pendidikan formal yang menangani berbagai macam karakteristik anak didik memerlukan pengamatan proses belajar dan mengajar yang inovatifdan kreatif dari berbagai pihak. (Efendi, Muhammad.2011)
Pembelajaran di kelas harus disesuaikan untuk menekankan pada keaktifan siswa serta suasana pembelajaran yang menyenangkan. Sehingga, mereka termotivasi dalam proses pembelajaran. Pembelajaran inovatif dapat mendorong guru dan siswa untuk selalu mengembangkan cakrawala ilmu pengetahuan mereka dan menerapkanya dalam kehidupan, sehingga mereka menjadi manusia kreatif. Atas dasar itu seiring dengan berkembangnya teknologi informasi yang sudah merambah ke dunia pendidikan khususnya sekolah, guru 
dituntut lebih kreatif dan inovatif dalam mengembangkan dan memanfaatkan teknologi maupun lingkungan yang ada dalam pembelajaran Georafi.(Iri Qunarti, 2003)

Pembelajaran geografi bertujuan untuk memberi bekal kemampuan dan sikap rasional serta permasalahan yang timbul akibat interaksi antara manusia dengan lingkungan berkaitan dengan bidang studi tersebut, untuk itu guru tentunya harus memiliki kualitas dalam pengajaran keterampilan dan kedisiplinan. Guru dituntut untuk kreatif dalam pembelajaran. Pemanfaatan lingkungan sebagai media belajar merupakan salah satu wujud dari kreativitas guru.

Menurut Zainuddin dan Pamungkas (2008:5) media adalah segala sesuatu yang dapat dipergunakan untuk menyalurkan pesan dan dapat merangsang pikiran, dapat membangkitkan semangat, perhatian, dan kemanusian siswa sehingga dapat mendorong terjadinya proses pembelajaran pada diri siswa. Sementara itu pembelajaran adalah sebuah proses komunikasi antara pembelajar, pengajar dan bahan ajar. Komunikasi tidak akan berjalan tanpa bantuan sarana penyampai pesan atau media. Untuk menyampaikan pesan pembelajaran dari guru kepada siswa, biasanya guru menggunakan alat bantu mengajar (teaching aids) berupa gambar, model, atau alat-alat lain yang memberikan pengalaman konkrit, serta motivasi belajar.

Pembelajaran Geografi merupakan kegiatan pembelajaran yang dirancang untuk memberikan pengalaman belajar yang melibatkan proses mental dan fisik melalui interaksi antar siswa, siswa dengan guru, lingkungan dan sumber belajar lainnya mencapai kompetensi dasar.
Pengalaman belajar yang dimaksud dapat terwujud melalui penggunaan pendekatan pembelajaran yang bervariasi dan berpusat pada siswa, pengalaman belajar memuat kecakapan hidup yang perlu dikuasai siswa.

Pelaksanaan pelajaran di luar kelas dapat dilakukan guru sesuai dengan kemampuan yang ada. Tujuan dari pengajaran di luar kelas untuk membawa siswa mengamati, dan mempelajari hal-hal yang dianjurkan secara langsung dalam keadaan yang sesungguhnya di lingkungan sekitarnya dan kemudian dihubungkan dengan materi pelajaran. Pelajaran atau kerja lapangan juga merupakan hal yang tak terpisahkan dari materi geografi yang baik, karena kegiatan lapangan itu bermanfaat untuk bahan persepsi, pembangkit minat dan perolehan pengetahuan serta bermakna (Suharyono, 1990).

Berdasarkan hasil survei peneliti atau observasi awal di SMA Negeri 1 LAWA, pada saat proses belajar mengajar yang berlangsung, diketahui bahwa siswa kurang aktif dalam proses pembelajaran, karena guru kurang menggunakan media ataupun model pembelajaran yang bisa membuat siswa lebih bersemangat dalam proses pembelajaran berlangsung, sehingga membentuk siswa yang lebih aktif dalam menanggapi setiap permasalahan pada mata pelajaran geografi dan hal tersebut berakibat kepada kemampuan yang dimiliki siswa tidak tersalur dengan benar. Sedangkan dalam pembelajaran geografi siswa dituntut untuk mengeluarkan seluruh kemampuan yang dimiliki, guna mencapai hasil belajar yang sesuai dengan tujuan pembelajaran. Berdasarkan hasil obsesvasi awal pada guru geografi di sekolah menunjukan bahwa data hasil belajar geografi siswa kelas XI IPS-1 
pada materi Lingkungan Hidup dan Pembangunan Berkelanjutan SMA Negeri 1 LAWA yang terdiri dari 24 orang siswa, yang memperoleh nilai $\geq$ 70 hanya 9 orang siswa atau 39\%, sedangkan siswa yang memperoleh nilai $<70$ sebanyak 15 orang siswa atau $61 \%$. Nilai tersebut masih tergolong rendah, karena dari KKM sekolah untuk mata pelajaran geografi yaitu 70 KTSP. Nilai tersebut tentunya perlu adanya perhatian dari berbagai pihak khususnya guru mata pelajaran geografi untuk melakukan alternatif baru dalam rangka perbaikan proses belajar mengajar untuk meningkatkan hasil belajar siswa.

Adapun kendala yang timbul dalam kegiatan pembelajaran adalah sarana belajar dan fasilitas yang ada di sekolah. Pada umumnya sarana belajar di sekolah yang kurang lengkap dan tidak nyaman menyebabkan siswa kesulitan dalam meningkatkan hasil belajarnya karena sarana yang kurang lengkap tersebut. Sekolah sebagai institusi pencetak generasi yang hidup di masa mendatang harus mempunyai kepedulian terhadap perkembangan teknologi yang terjadi. Jika tidak, maka siswa akan tertinggal dengan perkembangan zaman. Siswa yang terlibat aktif dalam pembelajaran memiliki penyimpanan yang lebih baik maupun mengembangkannya. Maka oleh karena itu, dengan kurangnya fasilitas di sekolah maka peneliti menggunakan pemanfaatan lingkungan sebagai media dalam pembelajaran Geografi untuk lebih bermakna disebabkan para siswa dihadapkan langsung dengan peristiwa dan keadaan yang sebenarnya dapat dipertanggung jawabkan. Guru juga berharap siswa akan lebih akrab dengan lingkungan sehingga menumbuhkan rasa cinta akan lingkungan sekitar. Kegiatan belajar lebih bermakna dan tidak membosankan di bandingkan duduk di kelas selama berjam-jam, sehingga motivasi belajar siswa akan lebih tinggi dan lebih bermakna sebab bahan-bahan yang dapat dipelajari lebih kaya serta lebih factual sehingga kebenarannya lebih akurat. Oleh karena itu peneliti memanfaatkan lingkungan sebagai media pembelajaran.

Pemanfaatan lingkungan sebagai media pembelajaran adalah kegiatan pembelajaran yang terkecil atau paling dekat dengan siswa. Lingkungan sifatnya relative menetap, oleh karena itu jenis lingkungan ini akan lebih mudah dikenal dan dipelajari oleh siswa.Dengan mempelajari Lingkungan Hidup dan Pembangunan Berkelanjutan melalui pemanfaatan lingkungan alam diharapkan siswa dapat lebih memahami gejala-gejala alam yang terjadi dalam kehidupannya sehari-hari. Melalui interaksi langsung dengan lingkungan dan alam sekitar akan menimbulkan penghayatan baru dalam diri siswa tentang keterkaitan antar berbagai lingkungan. (Rosmawati, 2011).

Lingkungan Hidup dan Pembangunan Berkelanjutan

a. Pengertian Lingkungan Hidup

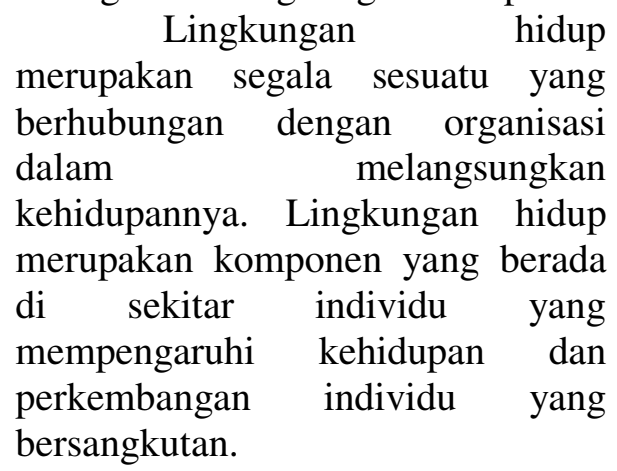

Dalam Undang-undang Republik Indonesia Nomor 23 Tahun 1997 tentang ketentuanketentuan pokok pengelolaan lingkungan hidup dinyatakan bahwa lingkungan adalah kesatuan ruang 
dengan semua benda, daya keadaan, dan makhluk hidup, termasuk di dalamnya manusia, dan perilakunya yang mempengaruhi kelangsungan perikehidupan dan kesejahteraan manusia serta makhluk hidup lainnya.

Secara umum lingkungan dibedakan menjadi dua, yaitu sebagai berikut :

1. Lingkunganbiotik/lingkungan abiotik

Lingkungan biotik adalah semua makhluk hidup yang menempati bumi, terdiri atas tumbuhan, hewan dan manusia. Menurut fungsinya faktor biotik dibedakan menjadi tiga, yaitu :

a) Produsen : organisme yang dapat menghasilkan makanannya sendiri, yang disebut autotrofik.

b) Konsumen : organisme yang hanya memanfaatkan hasil yang disediakan oleh organisme lain. Kelompok konsumen disebut heterotrofik.

c) Pengurai : organisme yang berperan menguraikan sisasisa atau makhluk hidup yang telah mati, seperti bakteri dan jamur.

$\begin{array}{rlr} & \text { Faktor-faktor } & \text { biotik } \\ \text { yang } & \text { membentuk } & \text { satuan } \\ \text { eksosistem : } & \\ \text { a) } & \text { Individu adalah sebutan } \\ & \text { makhluk hidup yang } \\ & \text { tunggal. } \\ \text { b) } & \text { Populasi adalah } \\ & \text { sekelompok individu } \\ & \text { sejenis yang menempati } \\ & \text { suatu daerah tertentu, dan } \\ \text { c) } & \text { Komunitas adalah } \\ & \text { seluruh populasi makhluk }\end{array}$

hidup yang hidup bersama-sama di suatu daerah tertentu.

2. Lingkunganabiotik/lingkunga $\mathrm{n}$ anorganik

Adalah benda-benda mati bumi, tetapi mempunyai pengaruh pada kehidupa makhluk hidup yang ada di dalamnya, antara lain udara, tanah, air, dan sinar matahari.

Komponen-komponen lingkungan yang ada di sekitar kita merupakan satu kesatuan yang saling mempengaruhi antara komponen yang satu dengan komponen yang lain yang disebut ekosistem. Ilmu yang mempelajari hubungan timbal balik antara komponen biotik dengan komponen abiotik dalam ekosistem disebut ekologi.

b. Pembangunan Berkelanjutan Pembangunan berkelanjutan adalah pembangunan yang memenuhi kebutuhan masa kini tanpa harus mengurangi kemampuannya untuk memenuhi kebutuhan dari generasi yang akan datang. Untuk menjaga kelestarian lingkungan agar kualitas lingkungan tetap terjaga, maka pembangunan berkelanjutan harus memperhatikan pemanfaatan lingkungan hidup dan kelestariannya.

Pembangunan berwawasan lingkungan adalah usaha-usaha dalam rangka meningkatkan kualitas hidup manusia dengan memperhatikan faktor lingkungan. Istilah berkelanjutan berasal dari bahasa inggris yaitu sustainability. Istilah berkelanjutan digunakan untuk konsep pembangunan. Pembangunan berkelanjutan adalah 


pembangunan dalam rangka
pemenuhan kebutuhan manusia
dengan memanfaatkan sumber daya
yang ada secara arif, bijaksana,
efisien, dan memperhatikan
pemanfaatan untuk masa kini dan
generasi yang akan datang. Menurut
Brundtland, pembangunan
berkelanjutan didefinisikan sebagai
pembangunan untuk memenuhi
kebutuhan sekarang tanpa
mengurangi kemampuan generasi
yang akan datang untuk memenuhi
kebutuhan mereka.
Konsep pembangunan
berkelanjutan pernah diutarakan
dalam KTT Rio De Jeneiro tahun
1992 dengan 2 gagasan utama, yaitu
gagasan kebutuhan dan gagasan
keterbatasan, setelah itu adanya
protokol Kyoto,
menyampaikan yang
pengurangan gas buang industri
negara-negara maju.
Secara garis besar,
pembangunan berkelanjutan
mempunyai ciri-ciri sebagai berikut
- Menjamin pemerataan dan
- keadilan kan
- Menghargai keaneragaman
hayati Menggunakan pendekatan
integratif Mengunakan wawasan dan
pandangan ke depan.

\section{METODE PENELITIAN}

Jenis Penelitian

Jenis penelitian ini adalah

Penelitian Tindakan Kelas (PTK).

Penelitian ini adalah suatu bentuk kajian yang bersifat reflektif oleh pelaku tindakan. Dalam prosedur pelaksanaanya dilakukan dengan proses pengkajian berdaur yang terdiri dari empat tahap yaitu: merencanakan, melakukan tindakan, mengamati, evaluasi dan refleksi.

Tempat dan Waktu Penelitian

$$
\text { Penelitian ini telah }
$$

dilaksanakan pada semester genap tahun ajaran 2017-2018 di kelas X1 IPS 1 SMA Negeri 1 LAWA pada materi pokok Lingkungan Hidup dan Pembangunan Berkelanjutan.

Subyek Penelitian

Subjek penelitian adalah siswa kelas X1 IPS 1 SMA Negeri 1 LAWA yang terdaftar pada semester genap tahun pelajaran 2017/2018. Jumlah siswa yang terdaftar pada kelas tersebut adalah 25 orang siswa yang terdiri dari 13 orang laki-laki dan 12 orang perempuan. Kelas ini dipilih sebagai subyek penelitian karena berdasarkan data hasil belajar siswa di kelas XI IPS 1 masih tergolong rendah.

Desain dan Prosedur Penelitian

Penelitian ini merupakan Penelitian Tindakan Kelas (PTK) yang melakukan proses pengkajian berdaur atau bersiklus dari berbagai kegiatan. Penelitian tindakan kelas ini dilaksanakan terdiri dari 2 (dua) siklus. Tiap siklus dilaksanakan indikator yang ingin dicapai setiap faktor yang akan diselidiki.

Menurut Wardani (2004:212) bahwa langkah dalam PTK merupakan satu daur atau siklus yang terdiri dari:

- Perencanaan (planning)

- Pelaksanaan tindakan (action)

- Observasi dan evaluasi (observation and evaluation)

- refleksi (reflection).

Secara rinci prosedur penelitian tindakan kelas setiap siklus adalah sebagai berikut:

1. Siklus I
a. Perencanaan 
Adapun yang dilakukan pada tahap ini adalah:

- Membuat skenario pembelajaran berupa rencana pelaksanaan pembelajaran (RPP) dengan memanfaatkan lingkungan sebagai sumber belajar.

- Membuat/menyiapkan media/alat bantu berupa lembar observasi keaktifan dan partisipasi aktif siswa dalam kegiatan pembelajaran.

- Mendesain alat evaluasi berupa penilaian proses dan hasil belajar (produk) untuk mengetahui hasil yang dicapai siswa setelah mengikuti kegiatan pembelajaran.

b. Tindakan

Kegiatan yang dilaksanakan pada tahap tindakan yaitu melaksanakan scenario pembelajaran dengan memanfaatkan lingkungan sebagai sumber belajar

c. Observasi dan evaluasi

Kegiatan observasi pada siklus ini dilaksanakan untuk mendapatkan informasi bagaimana observasi dilakukan oleh guru pengamat dengan menggunakan lembar observasi berupa pengamatan aktivitas siswa selama kegiatan pembelajaran. Pelaksanaan evaluasi pada siklus ini untuk mendapat informasi sejauh mana pemahaman siswa terhadap materi yang diajarkan. Evaluasi dilaksanakan dengan penilaian tes tertulis dalam bentuk esai tes serta kinerja guru dalam mengelolah pembelajaran. d. Refleksi

Pada tahap ini peneliti melaksanakan diskusi refleksi berdasarkan hasil yang didapatkan dalam tahap observasi dan evaluasi.Refleksi dilaksanakan untuk mengkaji yang telah dan belum dicapai. Hasil refleksi digunakan untuk menetapkan langkah-langkah lebih lanjut pada siklus berikutnya.

\section{Siklus II}

Siklus II dilaksanakan bila minimal indikator kinerja pada siklus I belum tercapai dengan prosedur sesuai pada siklus I dan dengan melaksanakan perbaikanperbaikan terhadap kekurangankekurangan yang terdapat pada siklus I.

Data dan Teknik Pengumpulan Data

1. Sumber Data

Sumber data penelitian adalah siswa yang meliputi :

a. Hasil observasi aktivitas belajar siswa

Data aktivitas siswa diperoleh dari lembar pengamatan yang di isi selama proses pembelajaran berlangsung. Data ini dianalisis dengan menggunakan rumus persentase:

$$
\mathrm{p}=\frac{f}{N} \mathrm{X} 100 \%
$$

keterangan:

$\mathrm{P}=$ Angka presentase aktivitas

$\mathrm{F}=$ Frekuensi aktivitas guru

$\mathrm{N}=$ Jumlah aktivitas keseluruhan 
tabel 3.1 Skor rata-rata aktivitas Siswa

\begin{tabular}{rc}
\hline Skor Rata-rata Aktivitas Guru & Kategori \\
\hline $\mathbf{0 \%} \leq \mathbf{N R}<\mathbf{4 0} \%$ & Tidak Baik \\
\hline $\mathbf{4 1 \%} \leq \mathbf{N R}<\mathbf{5 5 \%}$ & Kurang Baik \\
\hline $\mathbf{5 6} \% \leq \mathbf{N R}<\mathbf{7 0 \%}$ & Cukup \\
\hline $\mathbf{7 5 \%} \leq \mathbf{N R}<\mathbf{8 5 \%}$ & Baik \\
\hline $\mathbf{8 6 \%} \leq \mathbf{N R}<\mathbf{1 0 0 \%}$ & Sangat Baik \\
\hline (sumber : Ristima, 2017)
\end{tabular}

b. Hasil observasi aktivitas mengajar guru

Data aktivitas guru

diperoleh dari lembar pengamatan yang diisi selama proses pembelajaran berlangsung. Data ini dianalisis dengan menggunakan rumus

$$
\mathrm{p}=\frac{f}{N} \mathrm{X} 100 \%
$$

keterangan:

$\mathrm{P}=$ Angka presentase aktivitas

$\mathrm{F}=$ Frekuensi aktivitas guru

$\mathrm{N}=$ Jumlah aktivitas keseluruhan

persentase:

tabel 3.2 Skor rata-rata aktivitas guru

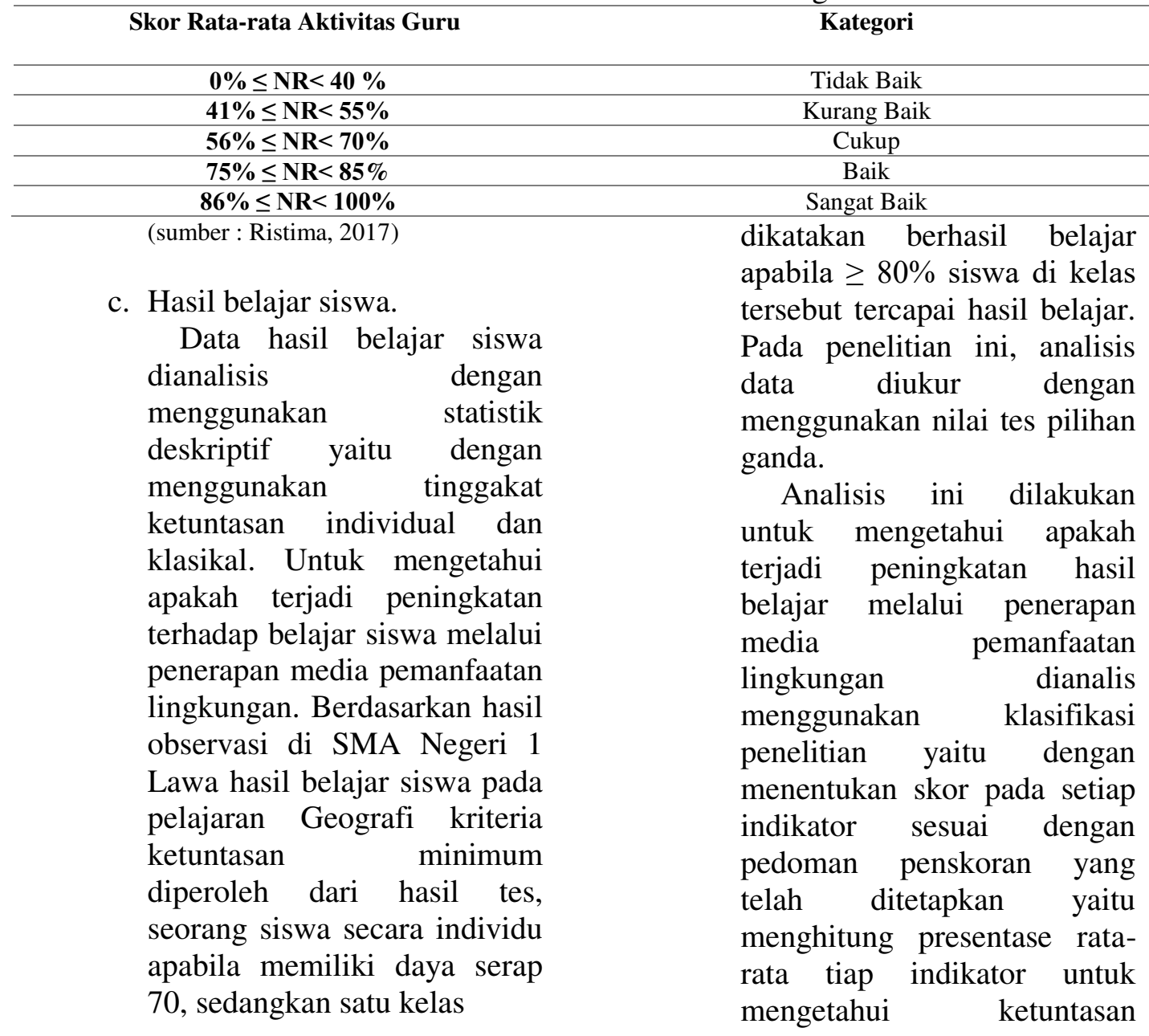


klasikal dan daya serap klasikal dari setiap indikator menggunakan rumus berikut:

$$
\begin{aligned}
& \mathrm{KS}=\frac{S T}{N} \times 100 \% \\
& \text { Keterangan: } \\
& \mathrm{KS}=\text { Ketuntasan Klasikal } \\
& \mathrm{ST}=\text { Jumlah Siswa yang Tuntas } \\
& \mathrm{N}=\text { Jumlah Siswa }
\end{aligned}
$$

(Nurjannah,2006)

2. Jenis Data

Data dalam penelitian ini dianalisis dengan menggunakan analisis deskriptif kuantitatif. Analisis deskriptif kuantitatif digunakan untuk menyajikan persentase aktivitas guru, presentase aktivitas siswa dan presentase ketuntasan hasil belajar siswa.

\section{Teknik Pengumpulan Data}

Data dikumpulkan dari hasil tindakan yang dilakukan pada proses observasi, proses belajarmengajar, tes hasil balajar, dan refleksi yang dijabarkan sebagai berikut:

a. Data tentang kondisi pelaksanaan pembelajaran dengan memanfaatkan lingkungan sebagai media pembelajaran.

b. Data tentang hasil belajar siswa sebagai tolak ukur penguasaan siswa pada materi lingkungan hidup dan pembangunan berkelanjutan dengan memanfaatkan lingkungan sebagai media pembelajaran.

\section{Instrumen Penelitian}

Instrumen penelitian ini terdiri atas tiga jenis, yaitu:

a. Lembar observasi pengelolaan pembelajaran pemanfaatan lingkungan sebagai media pembelajaran yang digunakan untuk memperoleh data aktivitas guru dalam mengelola pembelajaran

b. Lembar observasi aktivitas siswa yang digunakan untuk memperoleh data tentang aktivitas siswa.

c. Instrumen Tes Untuk Tes digunakan adalah esaites yaitu tes yang dilaksanakan pada setiap akhir siklus dan pilihan ganda pada tes refleksi, tes ini bertujuan untuk menganlisis peningkatan hasil belajar siswa

\section{HASIL PENELITIAN}

Siklus I dan Siklus II

Setiap Siklus terdiri atas tiga tahap yaitu perencanaan , tahap pelaksanaan, tahap pengamatan, dan refleksi.

a. Tahap perencanaan

Oleh karena pada siklus I instrumen penerapan hasil belajar yang telah diterapkan belum tercapai maka dilanjutkan dengan siklus II. Sebelum melaksanakan tindakan pada siklus II, guru juga telah mempersiapkan RPP II.

b. Tahap Pelaksanaan (Tindakan)

Siklus II dilaksanakan dalam satu kali pertemuan pada Jumat, 12 April 2018 jam pelajaran pertama dan kedua 70 menit. Secara kualitas kegiatan yang dilakukan selama proses pembelajaran pada siklus II lebih baik dari pada siklus I. Guru memberikan apersepsi mengulang meteri sebelumnya. Guru memberikan motivasi dengan menyampaikan kegunaan materi yang akan dipelajari yaitu siswa dapat memecahkan masalah seharihari, guru juga memberikan beberapa contoh pelaksanaanya. Hal 
tersebut membuat siswa lebih siap untuk mengikuti proses pembelajaran.

Kegiatan inti diawali dengan guru menyuruh siswa duduk berdasarkan kelompok yang telah dibagi sebelumnya dengan tiap kelompok terdiri dari 5 siswa yang beragama kemampuan akademik. Kegiatan selanjutnya yaitu guru membagi LKPD pada tiap kelompok untuk dipelajari dan dikerjakan. Siswa berdiskusi dan melaksanakan perintah-perintah yang diberikan di dalam LKPD. Guru membimbing siswa dan menjawab pertanyaan dari siswa yang bertanya. Guru meminta siswa mempresentasikan hasil kerja kelompoknya secara bergantian

c. Tahap Pengamatan (Observasi)
Observasi dilakukan selama proses pembelajaran siklus II berlangsung. Observasi dilakukan terhadap hasil belajar siswa pada pemanfaatan lingkungan sebagai media , kemampuan guru dan aktivitas siswa serta mencatat halhal yang terjadi selama pelaksanaan pembelajaran.

1. Observasi Aktivitas Guru dalam Mengelolah Pembelajaran

Pada

pengamatan

kemampuan menggunakan tahap ini, terhadap guru instrument yang berupa lembar observasi kemampuan guru. Data hasil observasi kemampuan guru dapat dilihat pada tabel dibawah ini :

Tabel 4.1: Lembar Observasi Guru dalam mengelolah pembelajaran pada siklus I dan Siklus II

\begin{tabular}{|c|c|c|c|c|c|c|c|}
\hline \multirow[t]{2}{*}{ NO } & \multirow[t]{2}{*}{ Aspek yang diamati } & \multicolumn{2}{|c|}{ Siklus I } & \multirow{2}{*}{$\begin{array}{c}\text { Rata- } \\
\text { rata }\end{array}$} & \multicolumn{2}{|c|}{ Siklus II } & \multirow{2}{*}{$\begin{array}{r}\text { Rata- } \\
\text { rata }\end{array}$} \\
\hline & & Pert.I & Pert.II & & Pert.I & Pert.II & \\
\hline \multirow[t]{3}{*}{1} & $\begin{array}{l}\text { Pendahuluan; } \\
\text { a. kemampuan } \\
\text { melakukan } \\
\text { apersepsi kepada } \\
\text { siswa sebelum } \\
\text { menyampaikam } \\
\text { tujuan } \\
\text { pembelajaran }\end{array}$ & 3 & 3 & 3 & 3 & 4 & 3,5 \\
\hline & $\begin{array}{l}\text { b. Kemampuan } \\
\text { memotivasi siswa } \\
\text { dengan } \\
\text { mengemukakan } \\
\text { kegunaan materi } \\
\text { yang akan di } \\
\text { pelajari }\end{array}$ & 4 & 4 & 4 & 3 & 3 & 3 \\
\hline & $\begin{array}{l}\text { c. Kemampuan } \\
\text { menyampaikan } \\
\text { tujuan } \\
\text { pembelajaran dan } \\
\text { menginformaskan } \\
\text { pembelajaran } \\
\text { melalui media }\end{array}$ & 4 & 4 & 4 & 4 & 4 & 4 \\
\hline
\end{tabular}


Jurnal Penelitian Pendidikan Geografi Volume 4. No 2 April 2019

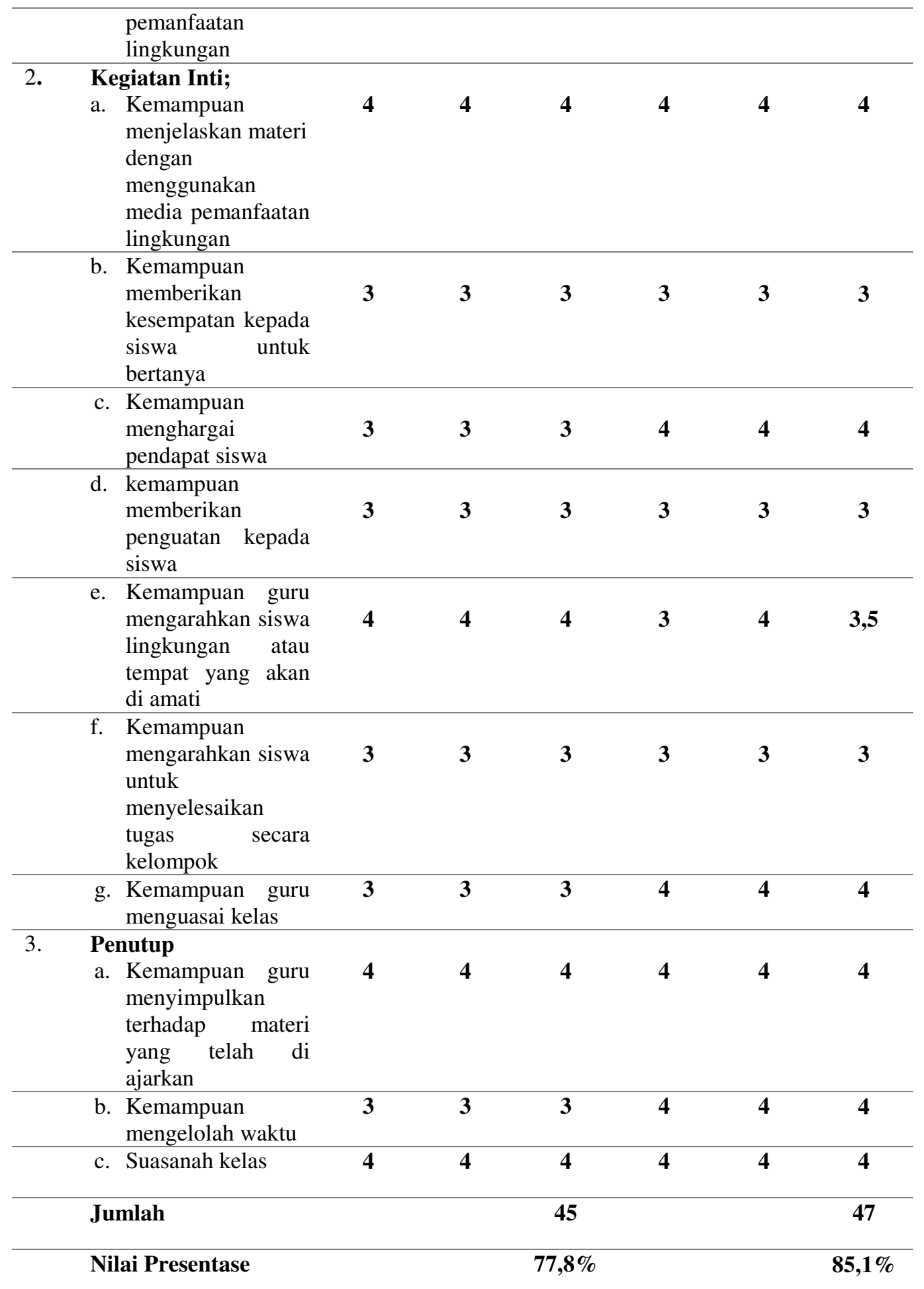

(Sumber: Data Hasil Observasi Aktivitas Siswa, 2018)

lingkungan mendapatkan skor

Berdasarkan Tabel

2.1menunjukkan bahwa

kegiatan pembelajaran melalui

media

pemanfaatan persentase Siklus I 77,8\%, untuk Siklus II $85,1 \%$ yang termasuk ke dalam kategori sangat baik. Hal tersebut membuktikan bahwa hasil 
yang diperoleh pada siklus II lebih meningkat dari siklus I.

2. Observasi Aktivitas Siswa Siklus I dan Siklus II
Hasil observasi aktivitas siswa pada siklus I dan Siklus II secara jelas disajikan dalam tabelberikut :

Tabel 4.2 Lembar Observasi Aktivitas Siswa selama Kegiatan pembelajaran siklus I dan siklus II

\begin{tabular}{|c|c|c|c|c|c|c|c|}
\hline \multirow[t]{2}{*}{ No } & \multirow[t]{2}{*}{ Aktiivitas yang diamati } & \multicolumn{2}{|c|}{ Siklus I } & \multirow{2}{*}{$\begin{array}{l}\text { Rata- } \\
\text { rata }\end{array}$} & \multicolumn{2}{|c|}{ Siklus II } & \multirow{2}{*}{$\begin{array}{c}\text { Rata- } \\
\text { rata }\end{array}$} \\
\hline & & Pert.I & $\begin{array}{l}\text { Pert. } \\
\text { II }\end{array}$ & & $\begin{array}{c}\text { Pert. } \\
\text { I }\end{array}$ & $\begin{array}{l}\text { Pert. } \\
\text { II }\end{array}$ & \\
\hline 1. & $\begin{array}{l}\text { Pendahuluan; } \\
\text { a. Siswa menjawab apresepsi }\end{array}$ & 2 & 2 & 2 & 2 & 2 & 2 \\
\hline & $\begin{array}{l}\text { b. Siswa mendengarkan } \\
\text { penyampaian guru }\end{array}$ & 3 & 3 & 3 & 3 & 3 & 3 \\
\hline & $\begin{array}{l}\text { c. Siswa mendengarkan tujuan } \\
\text { pembelajaran }\end{array}$ & 3 & 4 & 3,5 & 3 & 3 & 3 \\
\hline 2. & $\begin{array}{l}\text { Kegiatan Inti } \\
\text { a. Siswa } \\
\text { mendengarkan/memperhatik } \\
\text { an penjelasan guru }\end{array}$ & 4 & 4 & 4 & 3 & 4 & 3,5 \\
\hline & $\begin{array}{l}\text { b. Siswa menjawab pertanyaan } \\
\text { yang berhubungan dengan } \\
\text { materi }\end{array}$ & 3 & 3 & 3 & 4 & 4 & 4 \\
\hline & $\begin{array}{l}\text { c. Siswa antusias dalam } \\
\text { belajar }\end{array}$ & 3 & 3 & 3 & 3 & 3 & 3 \\
\hline & $\begin{array}{ll}\text { d. Siswa memahami materi } \\
\text { dengan menggunakan } \\
\text { media pemanfaatan } \\
\text { lingkungan }\end{array}$ & 3 & 3 & 3 & 3 & 4 & 3,5 \\
\hline & $\begin{array}{l}\text { e. Siswa menjawab pertayaan } \\
\text { guru }\end{array}$ & 3 & 3 & 3 & 3 & 3 & 3 \\
\hline & $\begin{array}{l}\text { f. Siswa menyelesaikan tugas } \\
\text { kelompok }\end{array}$ & 4 & 4 & 4 & 4 & 4 & 4 \\
\hline & $\begin{array}{l}\text { g. Siswa mengkondisikan } \\
\text { kelas }\end{array}$ & 3 & 4 & 3,5 & 4 & 4 & 4 \\
\hline 3. & $\begin{array}{l}\text { Penutup } \\
\text { a. Siswa menyimpulkan } \\
\text { materi } \\
\text { yang di ajarkan }\end{array}$ & 2 & 2 & 2 & 3 & 3 & 3 \\
\hline & $\begin{array}{l}\text { b. Kemampuan mengelolah } \\
\text { waktu }\end{array}$ & 3 & 4 & 3,5 & 3 & 4 & 3,5 \\
\hline & c. Suasana kelas & 4 & 4 & 4 & 4 & 4 & 4 \\
\hline & Jumlah & & & 41,5 & & & 43,5 \\
\hline
\end{tabular}


(Sumber: Data Hasil Observasi Aktivitas Guru, 2018)

Berdasarkan Tabel di atas hasil observasi aktivitas siswa pada Siklus I dan Siklus II terlihat siswa sudah mulai berkembang dari siklus I, yang masih kurang dalam berbagai hal seperti menyelesaikan masalah yang telah diberikan, lalu siswa masih kurang aktif dalam bertanya atau menyampaikan ide, di siklus II sudah meningkat. Sehingga aktivitas siswa sudah sesuai dengan
KBM (Kegiatan Belajar Mengajar). Hasil presentase yang diperoleh yaitu $80,4 \%$ yang termasuk dalam kategori baik.

3. Hasil Belajar Siswa Siklus I dan siklus II

Pada siklus I dan Siklus II ini, guru memberikan tes, yang dilaksanakan pada akhir pertemuan. Skor nilai tes siswa dapat dilihat pada tabelberikut:

Tabel 4.3 Hasil Belajar Siklus I dan Siklus II

\begin{tabular}{ccc}
\hline ST/BT & Siklus I & Siklus II \\
\hline ST & 8 & 22 \\
\hline BT & 17 & 3 \\
\hline Jumlah & 25 & 25 \\
\hline Ketuntasan Siswa & $56 \%$ & $88 \%$
\end{tabular}

(Sumber: Data Hasil Belajar Siswa 2018)

Berdasarkan pada Tabel di atas dapat diketahui jelas bahwa pada tes siklus I sudah ada 8 siswa yang tuntas belajarnya atau $56 \%$ dan siswa yang tidak tuntas sebanyak 17 orang siswa atau $76 \%$. Berdasarkan KKM yang ditetapkan di SMA Negeri 1 Lawa bahwa seorang siswa dikatakan tuntas belajarnya bila memiliki nilai ketuntasan secara individu minimal 70 dan ketuntasan secara klasikal $80 \%$. Dan hasil tes pada siklus II ada 22 siswa yang tuntas belajarnya atau $88 \%$ dan siswa yang tidak tuntas sebanyak 3 orang siswa atau $7 \%$ Oleh karena itu, dapat disimpulkan bahwa tes siklus II ketuntasan siswa secara klasikal dinyatakan tuntas.

d. Refleksi

Refleksi adalah kegiatan untuk mengingat dan melihat kembali semua kegiatan pada kegiatan siklus pembelajaran yang telah dilakukan, untuk menyempurnakan siklus berikitnya. Adapun hasil refleksi kegiatan pembelajaran silkuls I yaitu

Tabel 4.4 Refleksi Siklus I dan Siklus II

\begin{tabular}{llll}
\hline No & Refleksi & Hasil Temuan & Revisi \\
\hline $\mathbf{1}$ & Kemampuan Guru & Guru & Guru memperbaiki cara \\
\hline
\end{tabular}




\begin{tabular}{|c|c|c|c|}
\hline & & $\begin{array}{l}\text { 1. Guru kurang memberikan } \\
\text { penjelasan mengenai } \\
\text { lingkungan yang akan diamati. } \\
\text { 2. Guru kurang melakukan } \\
\text { apersepsi yang berhubungan } \\
\text { dengan materi, guru jarang } \\
\text { memberikan motivasi kepada } \\
\text { siswa. } \\
\text { 3. Guru kurang mengarahkan kepada } \\
\text { tiap-tiap kelompok untuk } \\
\text { melakukan kegiatan sesuai } \\
\text { dengan petunjuk dalam LKS. } \\
\text { 4. Guru kurang mengevaluasi dan } \\
\text { merefleksi terhadap hasil diskusi } \\
\text { siswa yang telah dipresentasikan. }\end{array}$ & $\begin{array}{l}\text { Mengajarkanmateri } \\
\text { pembelajaran yang sesuai } \\
\text { dengan model } \\
\text { pembelajaranpemanfaatan } \\
\text { lingkungan sebagai sumber } \\
\text { belajar, sehingga diharapkan } \\
\text { pada pertemuan selanjutnya } \\
\text { diperoleh peningkatan } \\
\text { aktivitas guru pada siklus } \\
\text { selanjutnya. }\end{array}$ \\
\hline & Aktivitas Siswa & $\begin{array}{l}\text { 1. Kurang mengajukan pertanyaan } \\
\text { mengenai hal-hal yang kurang } \\
\text { dipahami. } \\
\text { 2. Tidak mendengarkan penjelasan } \\
\text { guru mengenai LKS yang telah } \\
\text { dibagikan. } \\
\text { 3. Tidak semua siswa aktif dalam } \\
\text { bekerjasama mengerjakan LKS } \\
\text { kelompok. } \\
\text { 4. Kurang mendengarkan penjelasan } \\
\text { mengenai lingkungan yang akan } \\
\text { diamati, kurang } \\
\text { mendengarkan/memperhatikan } \\
\text { guru dalam menyampaikan tujuan } \\
\text { pembelajaran. }\end{array}$ & $\begin{array}{l}\text { Untuk pertemuan selanjutnya } \\
\text { guru hanya perlu } \\
\text { meningkatkan motivasi anak } \\
\text { untuk belajar.Guru harus } \\
\text { lebih memperhatikan dan } \\
\text { mengarahkan siswa agar } \\
\text { focus dan berkosentrasi } \\
\text { dalam mendengarkan atau } \\
\text { memperhatikanpenjelasan } \\
\text { guru, dalam menyelesaiakan } \\
\text { LKPD dan mengarahkan } \\
\text { siswa mempresentasikan hasil } \\
\text { LKPD tersebut. }\end{array}$ \\
\hline & Hasil Tes Awal & $\begin{array}{l}\text { 1. Dalam pembelajaran ini tampak } \\
\text { bahwa siswa kurang membaca } \\
\text { buku teks yang terkait dengan } \\
\text { materi yang dipelajari } \\
\text { 2. Siswa belum terbiasa } \\
\text { menggunakan media } \\
\text { 3. Siswa kurang memperhatikan pada } \\
\text { saat presentasi temanteman } \\
\text { kelompoknya. }\end{array}$ & $\begin{array}{l}\text { Peneliti mencoba melaku- } \\
\text { kan perbaikan dalam proses } \\
\text { belajar mengajar agar pada } \\
\text { siklus selanjutnya siswa yang } \\
\text { memenuhi ketuntasan belajar } \\
\text { dapat meningkat lagi seperti } \\
\text { yang diharapkan. }\end{array}$ \\
\hline
\end{tabular}

(Sumber: Data Refleksi 2018)

$\begin{array}{lr}\text { Dan kegiatan } & \text { siklus } \\ \text { pembelajaran yang } & \begin{array}{r}\text { telah } \\ \text { untuk } \\ \text { dilakukan, }\end{array} \\ \text { menyempurnakan } & \text { siklus } \\ \text { berikutnya. Karena siklus II ini } \\ \text { telah meningkat dari siklus I dan } \\ \text { sudah mencapai indikator yang } \\ \text { diinginkan, maka tidak adanya } \\ \text { refleksi di siklus II ini }\end{array}$

\section{PEMBAHASAN}

Berdasarkan hasil penelitian yang dilakukan dari tanggal 5 April 2018 sampai tanggal 19 April 2018 di SMA Negeri 1 Lawa, dengan melakukan penelitian terhadap kegiatan belajar mengajar dengan menggunakan lembar observasi guru dan siswa serta memberikan pemahaman kepada siswa tentang lingkungan observasi, LKPD, tes siklus I, tes siklus II awal akhir 
yang berbentuk Essay dengan jumlah lima soal dan tes akhir yang berbentuk pilihan ganda dengan jumlah sepuluh soal pada siswa kelas XI di SMA Negeri 1 Lawa. Proses belajar dilakukan selama dua kali pertemuan dalam 1 minggu.

Berdasarkan data yang telah dikumpulkan dalam penelitian, maka hal-hal yang perlu dibahas adalah sebagai berikut:

1. Aktivitas Guru dalam Mengelola Pembelajaran

Berdasarkan hasil

penelitian observasi kemampuan guru menunjukkan bahwa penelitian tindakan kelas dengan menggunakan media pemanfaatan lingkungan mengalami peningkatan yaitu, siklus I memperoleh hasil $77,8 \%$ yang termasuk kedalam kategori baik dan siklus II memperoleh hasil $80,4 \%$ yang termasuk kedalam kategori sangat baik. Adapun faktor yang menyebabkan adanya peningkatan kemampuan guru dalam pembelajaran karena guru selalu melakukan evaluasi pembelajaran saat berlangsungmya proses pembelajaran. Dimana guru dinilai oleh guru bidang

studi Pendidikan Geografi melalui lembar observasi kemampuan guru dalam mengelola pembelajaran saat berlangsungnya proses pembelajaran. Hasil observasi tersebut dijadikan tolak ukur guru mempertahankan yang sudah sangat baik dan meningkatkan pada aspek yang dianggap baik. Evaluasi pembelajaran merupakan suatu proses untuk menentukan manfaat dan peningkatan dari kegiatan pembelajaran melalui kegiatan penilaian. Jadi, berdasarkan hal demikian maka kemampuan guru akan meningkatka dengan memperbaiki kekurangan-kekurangan dari evaluasi pembelajaran.

Patta Bundu juga mengatakan bahwa penelitian tindakan kelas dengan menggunakan media pemanfaatan lingkungan secara keseluruhan semua kriteria aktifitas guru dan siswa serta analisis tes hasil belajar siswa dari siklus I ke siklus II mengalami peningkatan dan telah memenuhi kriteria yang ditetapkan pada setiap indikator.

Menurut Warkel berhasil atau tidaknya belajar, tergantung kepada bermacam-macam faktor. Salah satunya adalah faktor pengajar yang meliputi pengetahuan tentang materi pelajaran, ketrampilan mengajar, minat, motivasi, sikap, perhatian, kesehatan dan kondisi fisik pada umumnya.

Adapun faktor yang mendukung keberhasilan guru dalam mengelola pembelajaran antara lain adalah karena tersedianya media dan alat belajar seperti lembar kerja peserta didik (LKPD). Ngalim Purwanto mengatakan bahwa "sekolah yang cukup memiliki perlengkapan yang diperlukan untuk belajar ditambah dengan cara mengajar yang baik dari guru akan mempermudah dan mempercepat belajar anak-anak".

2. Aktivitas Siswa selama Pembelajaran

Berdasarkan hasil penelitian observasi aktivitas siswa melalui media pemanfaatan lingkungan menunjukkan bahwa siswa terlihat lebih semangat dalam mengikuti proses 
pembelajaran. Timbulnya rasa semangat siswa ini karena proses pembelajaran melalui pemanfaatan lingkungan dilengkapi dengan media nyata, sehingga siswa menjadi semangat dan tertarik memperhatikan penjelasan guru. Adanya media nyata tersebut memudahkan siswa untuk mendengar penjelasan yang disampaikan oleh guru .Hal ini sesuai dengan meningkatnya hasil observasi aktivitas siswa pada siklus I dengan nilai persentase $78,3 \%$ yang termasuk kedalam kategori baik dan siklus II dengan nilai persentase $83,3 \%$ yang termasuk kedalam kategori baik. Hasil penelitian menunjukkan bahwa pembelajaran dengan menggunakan pemanfaataan lingkungan sebagai media dalam menyelesaikan soal pada materi lingkungan hidup dan pembangunan berkelanjutan dapat membuat siswa aktif. Hal tersebut sebagaimana yang ditemukan oleh Azhar Arsyad, "media merupakan komponen sumber atau wahana fisik yang mengandung materi intruksional dilingkungan siswa yang dapat merangsang siswa untuk belajar".

Azhar Arsyad juga menyatakan bahwa "hasil belajar seseorang diperoleh dari pengalaman langsung (kongkret); Kenyataan yang ada dilingkungan kehidupan seseorang kemudian melalui benda tiruan, sampai kepada lambang verbal (abstrak),"Proses pembelajaran terasa lebih mengesankan bagi siswa.

\section{Hasil Belajar Siswa}

Berdasarkan hasil tes siklus I ada 19 siswa yang belum tuntas belajarnya (76\%), dan yang tuntas belajar 6 siswa $(56 \%)$ kategori ketuntasan siswa dalam pembelajaran secara klasikal adalah jika mencapai $80 \%$, sehingga ketuntasan belajar siswa secara klasikal pada siklus I belum tercapai. Tercapainya keberhasilan belajar ini tidak lepas dari usaha guru dalam memotivasi untuk setiap kali pertemuan. Sedangkan pada siklus II siswa yang tidak tuntas belajarnya adalah $4(16 \%)$ dari 25 siswa dan yang tuntas belajarnya adalah 21 siswa $(84 \%)$ kategori ketuntasan siswa dalam pembelajaran secara klasikal adalah mencapai $80 \%$.

Selanjutnya,pembelajaran pada siklus I dan II berakhir siswa menjawab soal tes akhir, siswa yang tuntas adalah 22 siswa $(88 \%)$ dan tidak tuntas 3 siswa (7\%).

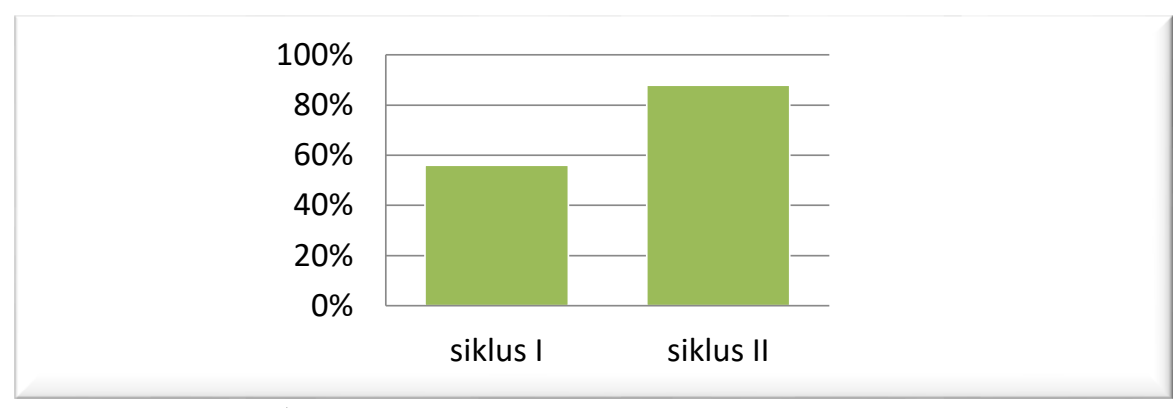

Gambar 4.5 Grafik Batang Peningkatan Hasil Belajar Siswa Siklus I dan II 


\section{KESIMPULAN}

Berdasarkan hasil penelitian yang dilakukan dikelas XI IPS 1 SMA Negeri 1 Lawa dengan subjek 25 siswa, maka dapat dikemukan kesimpulan dan saran-saran sebagai berikut:

1. Aktivitas guru selama proses pembelajaran dengan menggunakan media pemanfaatan lingkungan pada materi lingkungan hidup dan pembangunan berkelanjutan siklus I mencapai kategori baik dengan persentase $(77,8 \%)$ karena pada siklus I masih ada kekurangan yaitu guru kurang memotivasi siswa dan guru tidak mampu menguasai kelas pada saat proses pembelajaran berlangsung. Dengan beberapa kekurangan tersebut maka guru memotivasi siswa agar aktif untuk bertanya tentang apa yang belum mereka pahami dan memberikan reward kepada siswa sehingga ia lebih semangat dan termotivasi dalam proses pembelajaran. Dengan demikian pada siklus II mengalami peningkatan menjadi $(85,1 \%)$ dengan kategori sangat baik.

2. Aktivitas siswa selama proses pembelajaran dengan menggunakan media pemanfaatan lingkungan pada materi lingkungan hidup dan pembangunan berkelanjutan siklus I mencapai kategori baik dengan persentase $(78,3 \%)$ pada siklus I guru hanya perlu motivasi siswa untuk belajar, guru harus lebih memperhatikan dan mengarahkan siswa agar focus dan konsentrasi dalam memperhatikan penjelasan guru. Maka pada siklus II mengalami peningkatan menjadi $(80,4 \%)$ dengan kategori baik.
3. Peningkatan hasil belajar siswa pada materi lingkungan hidup dan pembangunan berkelanjutan dengan menggunakan media pemanfaatan lingkungan pada hasil tes siklus I ada 17 siswa yang belum tuntas belajarnya (76\%), dan yang tuntas 8 siswa $(56 \%)$ kategori ketuntasan siswa dalam pembelajaran secara klasikal adalah jika mencapai $80 \%$, sehingga ketuntasan belajar siswa secara klasikal pada siklus I belum tercapai. Karena pada siklus I siswa belum terbiasa belajar menggunakan media maka untuk memperbaiki hasil belajar guru memberi penjelasan bagaimana cara belajar menggunakan media, dengan demikian pada siklus II mengalami peningkatan siswa yang tidak tuntas belajarnya adalah $4(16 \%)$ dari 25 siswa dan yang tuntas belajarnya adalah 21 siswa $(84 \%)$ kategori ketuntasan siswa dalam pembelajaran secara klasikal adalah mencapai $80 \%$.

Guru diharapkan dapat menggunakan berbagai macam media pembelajaran yang sesuai dalam pembelajaran tematik khususnya geografi, sehingga minat siswa untuk belajar geografi semakin meningkat dan dapat meningkatkan ketuntasan belajar siswa.

\section{DAFTAR PUSTAKA}

Arikunto, S. 2001. Prosedur Penelitian Suatu Pendekatan Praktek. Jakarta: Rineka Cipta.

Arsyad Azhar. 2014. Media Pembelajaran. Jakarta. Rajawali Pers. 
Depdikbud. 1993. Kurikulum Sekolah Menengah Umum Landasan Program dan Pengembangan. Jakarta: Depdikbud.

Depdiknas. 2004. Pedoman Penunjang Kurikulum 2004 Pedoman Merancang Sumber Belajar. Jakarta: Depdiknas.

Depdiknas. 2001. Kurikulum Berbasis Kompetensi Mata Pelajaran Geografi untuk Sekolah Menengah Atas. Jakarta: Depdiknas.

Darwanto. 2007. Media Pembelajaran. Yogjakarta: Pustaka Pelajar.

Daryanto S. 1997. Kamus Bahasa Indonesia Lengkap. Surabaya: Apollo.

Dimyati dan Mudjio. 1994. Belajar dan Pembelajaran. Jakarta: DEKDIKBUD.

Efendi, $\quad$ Muhammad. 2011. Pengembangan Media Pengajaran. Tersedia di :http://geografiO8unlambanjarm asin.blogspot.comDiakses $\quad 05$ Februari 2018

Ghony M. Junaidi. 2008. Penelitian Tindakan Kelas, Malang: UIN Malang Press.

Iri Qurnati. 2003. Strategi Active Learning dan Praktekya dalam IPA. Jakarta: Rineka Cipta.
Hamalik, Oemar. 2003. Proses Belajar Mengajar. Bandung: Bumi Aksara

Ristima, Dkk. 2017.Penerapan Model Pembelajaran Kooperatif Tipe STAD untuk Meningkatkan Hasil Belajar IPA pada Siswa Kelas IV SD Inpres 2 Paringmpu, (Jurnal Kreatif Tadulako Online Vol. 6 No. 6/29/Mei/2017).

Rosmawati Dkk. 2011. Pemanfaatan Lingkungan Sebagai Sumber Belajar untuk Meningkatkan Hasil Belajar Siswa. Jurnal PTK Volume Khusus.

Suharyono.1990. Geografi dalam Dunia Ilmu dan Pengajaran Sekolah.Semarang: IKIP Semarang Press.

Sudjana dan Rivai. 2005. Media Pembelajaran. Bandung: Sinar Biru

Nurjannah. 2006. Efektivitas Modal Pembelajaran Quantum Teaching pada Materi Bilangan Bulat di SMPN 6 Banda Aceh, Skripsi. Banda Aceh: FKIP Unsyah.

Wardani. 2004. Penelitian Tindakan Kelas. Jakarta. 